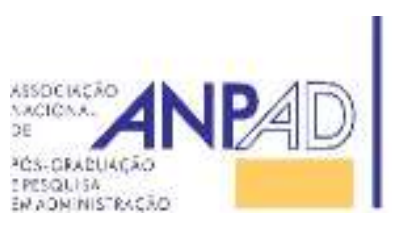
Available online at http://www.anpad.org.br/bar
BAR, Rio de Janeiro, v. 13, n. 1, art. 3, pp. 33-55, Jan./Mar. 2016

\title{
Effect of Nostalgia on Customer Loyalty to Brand Post-Merger / Acquisition
}

Ana Carolina Toledo ${ }^{1}$ Evandro Luiz Lopes ${ }^{1,2}$

Universidade Nove de Julho ${ }^{1}$ Universidade Federal de São Paulo ${ }^{2}$

Received 22 January 2015; received in revised form in 7 March 2016 (this paper has been with the authors for three revisions); accepted in 8 March 2016; published online 28 April 2016. 


\begin{abstract}
The main objective of this study is to identify the effect of nostalgic feelings on consumer loyalty to the prevailing brand following the extinction of a brand in a merger/acquisition process. We also propose an explanatory model of the relationships between tests of relevant constructs. Based on a review and theoretical reflection on the constructs under study, this paper outlines a theoretical model in which attitudes in relation to both extinct and prevailing brands mediate the relationship between nostalgic feelings and customer loyalty, which was subsequently analyzed by structural equation modeling. The results showed the effect of nostalgic feelings on customers' attitudes toward both extinct and prevailing brands and the influence of switching costs on building brand loyalty. The study contributed to the expansion of the theoretical framework on the subject of marketing by developing and validating a comprehensive model that adds to existing research, expanding the horizon of the study of the phenomenon.
\end{abstract}

Key words: nostalgia; brand attitude; brand loyalty; merger and acquisition. 


\section{Introduction}

The feeling of nostalgia, which is present in all individuals, can influence their relationships with other people, objects, and services. Nostalgia is a bittersweet feeling that consists of a longing for yesterday, evoking fond memories of the past (Werman, 1977). For marketing researchers, this concept is relevant for shaping the structures of consumer preference and has been studied since the 1990s.

Some researchers link nostalgia with an irreversible memory, a comfort in life periods, especially during times of interruption or loss, such as the end of a relationship (Hunt \& Johns, 2013; Muehling, 2013).

In Brazil, mergers and acquisitions are common business scenarios (Bittencourt, Paim, Cunha, \& Nascimento, 2015). As a result, some companies decide to discontinue an acquired brand, breaking the bond between it and the consumer. Consequently, the feeling of nostalgia can emerge and influence customer loyalty to the prevailing brand.

This study identifies the constructs that comprise the dimension of brand loyalty and how they are influenced by nostalgia. We started from the premise that consumer behavior is affected by feelings and attitudes (Gobe, 2010). Nostalgia for an extinct brand can generate a high degree of dissatisfaction. This may impact loyalty to the new company/brand and compromise a company's ability to maintain clients. The focus of this study was the banking industry, since aggressive competition in this sector has led institutions to seek an alternative to achieving organic growth by adopting strategies of horizontal growth, related to acquisitions/mergers. This study looked at how nostalgia affects customers' loyalty, which is manifested in their attitudes and reported behavior.

A relevant consumer behavior issue emerges, which has not been covered extensively in academic research: does evoking the feeling of nostalgia, arising from the exclusion of a particular brand after the merger of two companies, impact customer loyalty? To answer this question, this study examines the effect of nostalgia on consumer behavior and loyalty, especially following the extinction of a brand as a result of the merger/acquisition process. Furthermore, an explanatory model is proposed regarding the relationships between constructs that characterize the phenomenon in question.

To achieve the goal, the study was divided into two stages. First, a literature review aiming to provide a conceptual background of the relevant objects of study was conducted. This served as the basis for the design of a theoretical model of the relationship between the constructs. The second stage, to test the hypotheses regarding the outlined theoretical model, included a field survey, using a descriptive/quantitative approach, involving customers of two banks undergoing mergers/acquisitions, who kept their accounts in the remaining institution.

\section{Theoretical Frame}

The aim of this section is to review the main theoretical concepts on the topic in question.

\section{Nostalgia: definition and conceptualization}

The feeling of nostalgia, which evokes memories of the past, occurs in all individuals, influencing how they relate to other people, objects, and services. It is a term of Greek origin, composed of the words nóstos, which means return (home), and álgos, meaning pain, distress. It describes a yearning for an idealized past. It was first mentioned in clinical psychology literature to describe a disease, a form of depression or melancholy caused by homesickness, especially in times of war, reflecting the feelings of soldiers during long periods of absence (Boym, 2002). 
The term longing can be found in the literature since 1668 (Lefi \& Gharbi, 2011). This fundamental sense is inherent to the human condition and has pervaded studies in different fields of knowledge including: history, psychology, sociology, anthropology, and environmental psychology (Figueiredo-Neto \& Bacha, 2013). In marketing, particularly in matters pertaining to consumer behavior issues, specifically attitude toward a brand, advertising and intention to purchase, the construct of nostalgia has been the subject of increasing interest (Plutarco \& Botelho, 2012). Sugimori, Matsuda and Kusumi (2011) highlight the contradictory effects of nostalgic advertisements on nostalgia related to products and memories. Muehling and Pascal (2012) particularly exploit the explanatory effects of advertising nostalgia based on the degree of people's involvement.

Sedikides, Wildschut and Baden (2004) and Wildschut, Sedikides, Arndt and Routledge (2006) consider a cognitive evaluation that implies a positive emotion, evoking a direct/explicit connection between the present and the past, triggered by some interpersonal, social, or environmental stimulus. Along the same line, Holak and Havlena (1998), Chaplin (2000) and Davis (1979, as cited in Holbrook, 1993), treat nostalgia as a positive emotion, which can be represented by evoking the past, a way to recreate aspects of life history in the present. For Kaplan (1987), nostalgia means a yearning for the past, a means of recalling happy, pleasant and fun memories. Sedikides et al. (2004) consider it as a more positive reaction (pleasant feelings) than negative (unwanted sensations).

Hertz (1990) describes it as a negative emotion, something like a sense of the past hopelessly lost. On the other hand, Divard and Demontrond (1997) claim that nostalgia confers a bittersweet feeling for an experience, emphasizing it as a feeling of pleasure, but with a pinch of sadness. Nostalgia also refers to the "[...] idea of redemption from the past, an emotional reunion with a time lived with family roots" (Comasseto et al., 2013, p. 371).

Sedikides et al. (2004), based on empirical research, propose that the existential feeling of nostalgia fulfills three functions:

1. Improvement of the self through solidification and increased identity;

2. Support of the cultural worldview, and support of the regeneration of meaning;

3. Strengthening of relational ties and interpersonal connections.

The definitions of these authors do not cover, individually, the full range of aspects of the construct. However, we can highlight some universal elements not tied to the particular contexts in which each author has researched the topic:

1. Nostalgia is simultaneously a feeling, emotion, and mood;

2. Nostalgia refers to a sense of melancholy in relation to products, services, people, places, experiences, an idealized past, and, by extension, brands.

\section{Background and classification of nostalgia}

Nostalgia is associated with a feeling of longing. Individuals may experience a nostalgic feeling for their own pasts, or have a nostalgic feeling for other times that were not part of their own experiences. Stern (1992) introduces the concepts of Historical Nostalgia (The way it was) and Personal Nostalgia (That was the way I was). Muehling (2013) offers a contribution to research on these two aspects when analyzing the relative influence of historical and personal nostalgia on attitude toward a brand.

Those experiencing historical nostalgia express the desire to return to the past, which is accepted as better than the present (Stern, 1992). This feeling is not influenced by age and can be summarized by longing for the traditional and conservative values of the society or community in past periods. Thus is established a link to the past and the values associated with it. The Marketing literature mentions several factors that influence this type of nostalgia: individual propensity to nostalgia or to discontinuance; alienation and loss of sense of community; feeling that the authentic Golden Age has been lost, or is 
requiring to be rescued or preserved (Davis, 1979; Kanungo, 1979; Merchant \& Ford, 2008; Stern, 1992).

Marchegiani and Phau (2011), in pioneering research involving 292 respondents, emphasize the value of historical nostalgia for marketing management, examining the effect of this construct at three levels (high, moderate, and low) on cognitions, attitude toward advertising, attitude toward the brand, and purchase intention. The authors conclude that these elements are strongly affected by the highest level of historical nostalgia to which individuals are exposed.

The experience of individual nostalgia consists of idealized memories of the past and it has been characterized as a matter of a psychological nature, and assumes a clinical condition (Holak \& Havlena, 1998). This manifestation of nostalgia can be understood as the nostalgia of what was lived; including things, memories, and people from the past (Baker \& Kennedy, 1994), and it manifests itself with varying degrees of intensity from one individual to another (Goulding, 2001).

Previous studies prescribe a set of factors that can influence the intensity of that feeling (Batcho, 2013; Baumgartner, 1992; Merchant \& Ford, 2008; Sierra \& Mcquitty, 2007). The first factor is age, which can influence the degree of that feeling (Merchant \& Ford, 2008). As they age, progressing through their life cycle, people tend to become more nostalgic, remembering the days of their youth with intense feelings (Batcho, 2013; Sierra \& Mcquitty, 2007). Based on this assumption, we formulated the first research hypothesis, which considers a theoretical relationship tested in other studies but in a new context.

H1: There is a positive relationship between consumer age and the nostalgic sentiment, in a merger/acquisition of service brands.

The second factor considered is the propensity to experience nostalgia. It is believed that this factor is associated with personality, individual character, psychographic variables, aspects of lifestyle, and is an innate characteristic of the consumer (Holbrook, 1993; Holbrook \& Schindler, 1991). Previous studies describe the most nostalgic people as those with greater emotional conditioning; those who feel happier in times of joy, and the saddest, in times of sorrow (Batcho, 2013), and those who enhance the attitude and emotion constructs which are the determinants of nostalgia (Sierra \& Mcquitty, 2007).

Previous studies have found that an individual's age sometimes enhances nostalgic feelings (Goulding, 2001; Merchant \& Ford, 2008; Sierra \& Mcquitty, 2007). However, nostalgia also characterizes consumers of the same age at different levels. Research conducted by Holbrook (1993) and Holbrook and Schindler (1991) found that some individuals are more prone to nostalgia than others. The author considered people close in age, the tendency to be more nostalgic as well as potential aspects of each character, related to psychographic features, lifestyle or personal characteristics.

Consumers' individual differences related to the propensity for nostalgia, when combined with the nostalgic effects of age, highlight a trend toward nostalgic change, in which higher levels of tendency to nostalgia influence the nostalgic link being built and demonstrate the preferences of the consumer (Holbrook \& Schindler, 2003a).

When consumers are prone to feeling nostalgic, they tend to evaluate products from other generations more positively, which reinforces the idea that valuation differences cannot be solely linked to the tastes or individual cultural aspects, but also to individuals' readiness to feel nostalgic (Holbrook \& Schindler, 1991).

To formulate the following hypothesis (H2), we considered the factors that influence the individual to be more prone to feelings of nostalgia when evaluating the extinct or prevailing brand. Even though this relationship has previously been tested (Batcho, 2013), we also expected to verify this relation in the context of mergers and acquisitions.

H2: There is a positive relationship between the propensity to experience nostalgia and nostalgia as measured in clients who have gone through a merger/acquisition. 
The third factor to be raised was the influence of individual experiences. As far as we know, the more intense experiences the individual has, the stronger the memories associated with them (Baumgartner, 1992; Merchant \& Ford, 2008).

The fourth antecedent factor of nostalgia is experiential discontinuity (Davis, 1979). An individual who has lived through a negative and stressful experience and who tends to suffer depression and expresses negative feelings, tends to seek inner compensatory mechanisms (defenses) to achieve stability, security, and continuity (Merchant \& Ford, 2008).

Concerning the constructs of nostalgia and fidelity, the studies presented in the 1980s and 1990s focused their interests on a consumer response (Bellaaj Gargouri \& Akrout, 2008), attempted to evaluate the elements of nostalgia proneness, and identify perceived characteristics on individual experience (Holbrook \& Schindler, 2003b).

Between the years 1980 and 1990, studies identified the influence of a sense of nostalgia on consumer attitude toward brands as a result of advertisements (Stern, 1992). Nostalgic attachment was reflected in the relationship of the consumer with the brand, influencing the degree of association of the brand with the concept in two respects: nostalgic attachment and perception of image congruence (Fournier, 1998).

From the perspective of marketing, the theme has been emphasized in a number of persuasive communication strategies and addressed in research on consumer behavior, particularly in the evaluation of brand loyalty, consumer preferences, collective memory, and emotions (Muehling \& Sprott, 2004).

With respect to the scope of this study, we sought to identify the influence of nostalgia in the brand replacement process, using as the locus a merger of two financial institutions. In the merger, there was prevalence of the brand of the institution that undertook the acquisition and the exclusion of the brand of the purchased company. It was assumed that the merger would arouse strong feelings of nostalgia in customers who had to migrate their accounts to the prevailing institution.

\section{Attitude to brands}

The brand influences customers' relationships with the company, using cognitive aspects (rational level), affective aspects (emotional level) and behavioral aspects, and these translate into attitudes, beliefs, and ultimately, loyalty (Gobe, 2010). These constructs are considered as the first responses in a system where environmental stimuli act as the input. The stimuli are processed in the consumer's mind in light of perception, conscience, and feelings (desires), generating a sequence of results that culminate in a response of acceptance or rejection of the object (Foxall, Goldsmith, \& Brown, 1998).

\section{Attitude and constituted components}

Fishbein and Ajzen (1975 as cited in Garrán, 2006) define attitude as a learned predisposition to respond in a consistently favorable or unfavorable manner to a given object (person, idea, product, service, brand, place, event, location); it is a feeling associated with beliefs, intentions, and behaviors.

The literature on attitudes toward the brand is very wide-ranging and the areas targeted by the researchers are so fragmented that the cognitive and affective components and processes involved are often studied in isolation, neglecting their joint effects. Integrative studies on the determinants and moderators of attitude are rare (Najmi, Atefi, \& Mirbagheri, 2012). Oliveira and Ferreira (2012) investigated the behavioral component in a marketing context, aiming to study the experiential assessment that consumers make about a brand and how that assessment influences attitudes toward the brand and purchase intention of the consumers. They concluded that the attitude toward the brand has a positive and significant influence on purchase intent, but such influence is not higher in the group of consumers who value all dimensions of experience. 
The bond that consumers have with a brand depends on their attitudes. The choice decisions are based more on intangible characteristics, symbolic aspects, brand personality, and established mental associations, than on the functional characteristics of the product (Ellwood, 2004). It is also known that there is a relationship between the brand and the user's identity (Almeida, Mazzon, Dholakia, \& Müller, 2011; Almeida, Mazzon, Müller, \& Dholakia, 2012).

In this study, we sought to assess the influence of a sense of nostalgia on the attitude toward the extinct brand after a merger, as well as the attitude toward the prevailing brand and the relationship between the extinct brand versus the prevailing brand, leading to the formulation of the third hypothesis.

H3a: There is a positive relationship between the nostalgic feeling and attitude in relation to the former brand.

H3b: There is a negative relationship between nostalgic sentiment and attitude toward the prevailing brand.

H3c: There is negative relationship between attitude toward an extinct brand and the attitude to the prevailing brand.

\section{Brand loyalty: background and methods}

The continuity of the relationship between the consumer and the holder of a particular brand leads to the feeling of complicity between them, thereby establishing a relationship of loyalty (Oliver, 1999). This can result in repeat purchases of the same brand, or consumers who consider the purchase of the same brand exclusive (Matos, 2011; Newman \& Werbel, 1973).

Dick and Basu (1994) completed the psychological study of loyalty to infer constraints on the set of motivations that influence the consumer to decide on the choice of a brand, suggesting a new element analysis, the attitude concerning the evaluation of one brand versus another brand. The authors describe three groups of variables or aspects that are antecedents to loyalty: cognitive variables, represented by the beliefs and perceptions regarding the product; affective variables, translated by a strong sense of liking for the brand; and conative variables indicated by repurchase intention.

The contemporary view of Marketing understands that loyalty has two approaches that should be considered simultaneously (Sheth, Mittal, \& Newman, 2001). The first, called behavioral loyalty, refers to aspects of buying behavior, such as the brands that people buy. It occurs when a customer repeatedly buys a product or service from the same brand, representing the lowest level of involvement. This can occur solely due to the lack of viable alternatives (Keller, 2003). The second approach, defined as attitudinal loyalty, is linked to attitudes toward the brand, i.e., how people feel about the brand. Studies on the value of the brand, according to a relational approach, observe stronger customer involvement when it comes to the attitudinal aspect (Brito, 2010; Keller \& Lehmann, 2006). In these cases, the client expresses a positive attitude toward a particular brand rather than simply making a repeat purchase of it. This does not mean that the repurchase of the brand products will be held in all situations but reveals that, in the set of alternatives available to the customer, the brand in question will emerge as one of their top choices (Brito, 2010).

Analyzing the brand associations as a central element of brand equity based on the client, Romaniuk and Thiel (2013) found that behavioral loyalty is a desirable outcome of brand equity. The authors conclude that there is a relationship between past and current behavioral loyalty and propensity to make associations. The results also revealed a positive relationship in situations where consumers with higher purchase frequency are most likely to make brand associations. Brakus, Schmitt and Zarantonello (2009) distinguish several dimensions of experience and build a range of brand experience that includes four dimensions: sensory, affective, intellectual (cognitive), and behavioral. The results of the aforementioned studies allow us to infer the impact of experience on loyalty and how that loyalty can be affected in cases of the abolition of a particular successful brand. 
In short, loyalty is built and evaluated longitudinally and without the intervention of occasional events that disrupt the links between customer and company, such as in the case of a merger of two companies, each of which have established brands and presumably loyal customers (Keller \& Lehmann, 2006). Such events can affect attitudes and loyalty, suggesting investigation of the prevalence and persistence of a dominant brand during the extinction of the acquired company's brand that could damage the relationship with old customers who were loyal to the company with the discontinued brand.

This reasoning leads to the formulation of hypotheses concerning the influence of emotional antecedents in the continuity of the relationship and the influence of the nostalgia dimension in brand loyalty, in a scenario of brand extinction in the wake of a merger/acquisition:

H4a: There is a negative relationship between attitude toward extinct brands and consumer loyalty, after the process of merger and acquisition.

H4b: There is positive relationship between the attitude towards prevailing brands and consumer loyalty, after the process of merger and acquisition.

Nostalgia can affect loyalty at both the attitudinal and behavioral level, leading to the fifth hypothesis:

H5a: In a situation of mergers and acquisitions, there is a positive relationship between behavioral loyalty and consumer loyalty to the prevailing brand.

H5b: In a situation of mergers and acquisitions, there is a positive relationship between attitudinal loyalty and consumer loyalty to the prevailing brand.

\section{Loyalty and switching costs}

The management of customer relationships, seeking their satisfaction, retention, and achievement of loyalty is a critical process in most business scenarios (Larán \& Espinoza, 2004). To this end, several academic studies have been conducted to enable a better understanding of the manifestations of loyalty, its antecedents, and consequential moderators, including switching costs (Gastal, 2005; Gonçalves, Gonçalves, Ferreira, \& Veiga, 2009; Perillo, 2007).

Satisfaction is recognized as a key antecedent of loyalty, even though we cannot rely on its management for customer retention (Gastal, 2005). Previous studies have observed the effect of switching costs on customer loyalty (Gastal, 2005; Gonçalves et al., 2009) and found that the trade-off caused by switching costs may induce an artificial loyalty (Gonçalves et al., 2009).

Costs can be understood as those that the consumer associates with a change from one brand/company to another, which may be linked to contractual and operational conditions or aspects of stress, wear, spent time, and the money factor (Burnham, Frels, \& Mahajan, 2003). Burnham, Frels and Mahajan (2003) gathered eight groups of switching costs and identified three new subsets, adding that its significance in the intent to switch providers may be higher than the actual consumer satisfaction with company. The authors associate the cost of change with the costs of lost time and effort. The financial costs of change are understood as quantifiable monetary losses, and finally, there are the costs of relational changes, involving psychological or emotional distress due to the rupture of ties.

Switching costs represent a barrier to exiting the relationship of loyalty between the company and the customer. They may be so high that they discourage change, favoring the maintenance of the link to the original brand (Gastal, 2005). In this regard, in repurchase processes, switching costs can be considered as a source of competitive advantage and a power factor of the companies over the consumer (Klemperer, 1995).

Switching costs assume importance and significance as a variable to be considered when it comes to analyzing and evaluating brand loyalty. In fusion processes, it is considered that the banking customer will be faced with a decision to maintain their relationship with a particular institution, or change, which 
involves the severance of the emotional bond with the extinct brand and the costs of changing institutions.

In addition to the emotional costs, bank customers also have to deal with other switching costs in the transition process between financial institutions (Ho, 2015). It is reasonable to assume that during the transition between banks, other costs would include consumer time and energy to change basic and relevant services such as debit accounts, cancellations and acquiring new forms of obtaining insurance and financing (Kim, Kliger, \& Vale, 2003), replacing credit cards (Shen, 2014), and other means of payment that customers are used to (Ho, 2015; Kim et al., 2003). Moreover, in Brazil, it is very common for employers to decide which bank pays the salaries of employees (Ferreira \& Lima, 2014), resulting in the biggest barrier to the exchange of consumer banking institutions. Therefore, we propose the following hypothesis:

H6: The higher the perceived switching costs, the greater the degree of loyalty of the consumer in a scenario of merger/acquisition of brands.

The formulation of explanatory hypotheses regarding the relationship of the constructs considered in the study design allowed a theoretical model. Empirical verification of this model will be based on the assumptions made. Figure 1 depicts the proposed model.

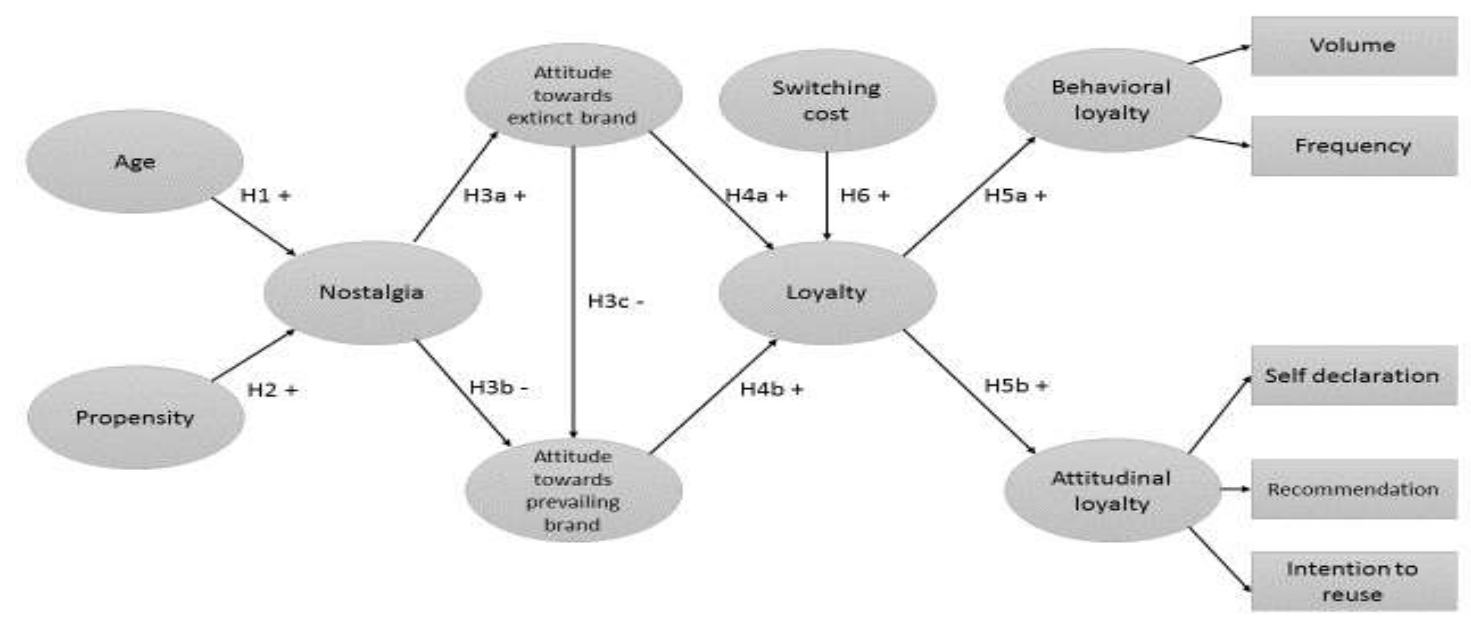

Figure 1. Theoretical Model of the Study

\section{Empirical Research}

The purpose of this section is to describe the procedures and results of an integral empirical research study.

\section{Method}

Given the nature of the research question, context, and goals of the study, we have chosen to conduct a descriptive and quantitative study, as a more appropriate research alternative, as we sought to identify the characteristics of the phenomenon to find explanations for relationships (Richardson, 1989).

\section{Instrument for data collection}

In accordance with the assumptions of the study, we adopted a formally structured online as a research instrument, applied anonymously. To collect data we used the QuestionPro. 


\section{Scales}

The scales used for the construction of the instrument collection and analysis of results were based on the analysis presented in the theoretical framework. We used a seven-point Likert scale, ranging from 1 - totally disagree to 7 - strongly agree. A 7-point scale was chosen, based on established models, which would also enable amplitude to be measured effectively.

To identify propensity to nostalgia, we used the scale proposed by Holbrook (1993), adapted by the authors, containing eight items. To this end, the original items were submitted to reverse translation and validated in Portuguese, as recommended in the literature (Devellis, 2003).

To measure the construct of Loyalty, the attitudinal and cognitive aspects of trust, presented by Dick and Basu (1994) were adapted to the concept of banking. The measurement consisted of twelve items. The same fitting was performed on the items of the scale of switching cost, which was based on the five items proposed by Burnham et al. (2003).

Attitudes in relation to extinct brands and prevailing brands were translated and adapted from the Mathwick and Rigdon scale (2004), consisting of seven items for each construct. Table 1 presents the items that make up the questionnaire:

Table 1

Scales

\begin{tabular}{|c|c|c|}
\hline Constructs & Subtitles & Affirmatives \\
\hline \multirow{8}{*}{$\begin{array}{l}\text { Propensity } \\
\text { to nostalgia }\end{array}$} & NOST1 & Nothing is made as it used to be anymore. \\
\hline & NOST2 & Things used to be better in the good old days. \\
\hline & NOST3 & The quality of products and services has increasingly deteriorated. \\
\hline & NOST4 & Technological changes will ensure a better future. * \\
\hline & NOST5 & History involves constant improvement in human welfare. * \\
\hline & NOST6 & We are experiencing a decline in the quality of life. \\
\hline & NOST7 & The constant growth of GDP has increased human happiness. * \\
\hline & NOST8 & Modern business often builds a better future.* \\
\hline \multirow{7}{*}{$\begin{array}{l}\text { Attitude in } \\
\text { relation with } \\
\text { extinct } \\
\text { brand }\end{array}$} & ATIT_REAL1 & I used to like to use the services of Banco Real. \\
\hline & ATIT_REAL2 & Among the various available bank services, Banco Real was the best. \\
\hline & ATIT_REAL3 & When I used the services of Banco Real, I felt I was getting a good deal. \\
\hline & ATIT_REAL4 & I used to praise the products and services of Banco Real to other people. \\
\hline & ATIT_REAL5 & I used to feel good making deals with Banco Real in the years that have passed. \\
\hline & ATIT_REAL6 & To me, Banco Real was easily my favorite bank. \\
\hline & ATIT_REAL7 & I believe that Banco Real was a great bank. \\
\hline
\end{tabular}

Continues 
Table 1 (continued)

\begin{tabular}{|c|c|c|}
\hline Constructs & Subtitles & Affirmatives \\
\hline \multirow{7}{*}{$\begin{array}{l}\text { Attitude in } \\
\text { relation with } \\
\text { prevailing } \\
\text { brand }\end{array}$} & ATIT_SANT1 & I like to use the services of Banco Santander. \\
\hline & ATIT_SANT2 & $\begin{array}{l}\text { Among the many bank services available, Banco Santander's services are the } \\
\text { best. }\end{array}$ \\
\hline & ATIT_SANT3 & When I use Santander's services, I always feel I am getting a good deal. \\
\hline & ATIT_SANT4 & I praise the products of Banco Santander to other people. \\
\hline & ATIT_SANT5 & I believe Santander is a great bank. \\
\hline & ATIT_SANT6 & To me, Banco Santander is easily my favorite bank. \\
\hline & ATIT_SANT7 & I will feel satisfied as a Banco Santander client in the next few years. \\
\hline \multirow{5}{*}{$\begin{array}{l}\text { Switching } \\
\text { Costs }\end{array}$} & CM1 & I have no time to obtain the information necessary to evaluate other banks. \\
\hline & $\mathrm{CM} 2$ & $\begin{array}{l}\text { Changing Banco Santander for another commercial bank would be too much } \\
\text { work. }\end{array}$ \\
\hline & $\mathrm{CM} 3$ & $\begin{array}{l}\text { I would lose the benefits of being a longstanding client if I left Banco } \\
\text { Santander. }\end{array}$ \\
\hline & $\mathrm{CM} 4$ & $\begin{array}{l}\text { Exchanging Banco Santander for a new bank would involve some new input } \\
\text { costs (fees, deposits etc.) }\end{array}$ \\
\hline & CM5 & $\begin{array}{l}\text { I would have to spend a lot of money to cover all the costs involved in changing } \\
\text { banks (examples: discharge loan, taxes, withdraw of funds, direct credit, } \\
\text { credit/debit cards, etc.) }\end{array}$ \\
\hline \multirow{8}{*}{$\begin{array}{l}\text { Attitudinal } \\
\text { Loyalty }\end{array}$} & LEAL_AT1 & I really appreciate Santander's services. \\
\hline & LEAL_AT2 & Santander, as a commercial bank, is not as good as I had thought.* \\
\hline & LEAL_AT3 & I like Banco Santander. \\
\hline & LEAL_AT4 & I recommend Santander to my friends. \\
\hline & LEAL_AT5 & I consider myself loyal to Banco Santander. \\
\hline & LEAL_AT6 & I intend to keep my account in Banco Santander for a long time. \\
\hline & LEAL_AT7 & I often consider the possibility of changing my bank.* \\
\hline & LEAL_AT8 & $\begin{array}{l}\text { In my future financial transactions, I will certainly make my financial } \\
\text { transactions with Banco Santander. }\end{array}$ \\
\hline \multirow{4}{*}{$\begin{array}{l}\text { Behavioral } \\
\text { Loyalty }\end{array}$} & LEAL_COMP1 & I put all my banking transactions in Banco Santander. \\
\hline & LEAL_COMP2 & $\begin{array}{l}\text { Since the merger of Banco Santander and Banco Real I have increased my } \\
\text { relationship with Santander. }\end{array}$ \\
\hline & LEAL_COMP3 & $\begin{array}{l}\text { Of the total number of times I use a bank, I think I use Banco } \\
\text { Santander } \% \text { of the time. }\end{array}$ \\
\hline & LEAL_COMP4 & $\begin{array}{l}\text { Of my total volume of investments (savings, funds, CBD, security), I have } \\
\% \text { in Banco Santander. }\end{array}$ \\
\hline
\end{tabular}

Note. *Inverted scales.

\section{Sample, field procedures and data analysis plan}

After conducting a pre-test to gauge understanding of the items, the questionnaire was applied at two higher education institutions in the city of São Paulo. The invitation to participate in the study, containing the link that directed to the electronic questionnaire, was forwarded by e-mail to people on a 
mailing list provided by the human resources department of the institutions and personal friends of the researchers.

The research sample was comprised of clients of Banco Santander inherited from ABN Amro/Real. The chosen sample was not probabilistic, with selection by convenience (Cooper \& Schindler, 2003). In the sampling design, customers who were employees of one of the two institutions were discarded. The choice of a non-probabilistic sample was due to the inaccessibility of the population, since the data of account holders are safeguarded by bank secrecy.

The sample is composed of clients who remained in business relationships with Santander Bank. It was decided that customers who left the bank following the acquisition of the extinct brand would not be included in this study as their behavior is considered disloyal. A total of 659 accesses to the online questionnaire created the sample. After applying the filters, which ruled out those respondents whose characteristics did not match those established in the sample design stage, 205 (31.1\%) respondents remained, with questionnaires completed in full.

Due to the nature of the variables under study and the scope of the research, we adopted the technique of structural equation modeling (SEM) for statistical analysis, because this statistical technique is most suitable for testing hypotheses regarding the relationships between variables (Hair, Money, Babin, \& Samouel, 2005). The preparation of the database followed the procedures outlined by Hair, Money, Babin and Samouel (2005) and Cooper and Schindler (2003), by identifying outliers and analysis of multicollinearity and normality of the variables.

\section{Analysis of Results}

The results of the study are presented in this section.

\section{Sample profile}

The final sample for this study consisted of 205 individuals with $54.3 \%$ men $(\mathrm{n}=111)$ living in São Paulo. The majority $(86 \% / \mathrm{n}=176)$ are 31 to 50 years old and have a high educational level $(98 \%$ $[\mathrm{n}=201]$ with undergraduate or graduate degrees). Concerning their monthly individual income, most claim that they earn over $\mathrm{R} \$ 5,241.01(70.9 \% / \mathrm{n}=145)$ and the majority provide services in private sector $(n=155 / 75.5 \%)$ organizations.

The sample is mainly composed of individuals who have at least two bank accounts. Of the total, $64.9 \%(\mathrm{n}=133)$ used the ABN main bank and, after the merger, $30.1 \%$ of the clients of the extinct bank migrated to another prime bank. Migrations to other banks also occurred, as shown Table 2. The time that respondents cumulatively maintained their accounts at the Santander and ABN banks ranged from 5 to 10 years, for $38.2 \%$ of respondents. Another fact is that $60.8 \%$ maintain a single checking account. 
Table 2

Main Bank before the Merger versus Current Main Bank

\begin{tabular}{|c|c|c|c|c|c|c|c|}
\hline $\begin{array}{c}\text { Main Bank } \\
\text { before merger }\end{array}$ & $\begin{array}{l}\text { Main current } \\
\text { Bank }\end{array}$ & $\mathbf{n}$ & $\%$ & $\begin{array}{c}\text { Main Bank } \\
\text { before merger }\end{array}$ & $\begin{array}{l}\text { Main current } \\
\text { Bank }\end{array}$ & $\mathbf{N}$ & $\%$ \\
\hline \multirow{6}{*}{ Banco ABN Real } & Banco do Brasil & 11 & 8.3 & \multirow{6}{*}{ Others } & Banco do Brasil & 13 & 17.6 \\
\hline & Bradesco & 3 & 2.3 & & Bradesco & 8 & 10.8 \\
\hline & Itaú & 20 & 15.0 & & Itaú & 22 & 29.7 \\
\hline & Santander & 93 & 69.9 & & Santander & 28 & 37.8 \\
\hline & Caixa Econômica & 4 & 3.0 & & HSBC & 1 & 1.4 \\
\hline & Others & 2 & 1.5 & & Caixa Econômica & 2 & 2.7 \\
\hline Total & & 133 & 100.0 & Total & & 72 & 100.0 \\
\hline
\end{tabular}

Analysis and disposal of outliers

To evaluate the existence of outliers, we resorted to the Mahalanobis distance technique, resulting in an average of 27.88 and a standard deviation of 14.69, and maximum values of 69.59 and minimum of 2.92 without a record capable of eliminating outliers.

\section{Verification of multicollinearity}

To assess the degree of multicollinearity (Hair et al., 2005), the calculation of the variance inflation factor (VIF) was used. In the analysis performed on all variables, the VIF was lower than 10, revealing a low degree of collinearity between the variables.

\section{Testing for normality}

The normal distribution of variables was analyzed with the Kolmogorov-Smirnov test using the parameters recommended by Field (2009). None of the variables had a normal distribution. Moreover, the items of the scale showed a high degree of skewedness and kurtosis. The non-normality confirmation led to the use of the PLS-analysis method by using SEM SmartPLS2.0M3 software. This technique is suitable for testing and validating exploratory models (Hair et al., 2005; Henseler, Ringle, \& Sinkovics, 2009). Chin and Newsted (1999) recommend the use of this method when an explanatory analysis in situations of high complexity is required, but little information is available.

\section{Testing the convergent validity}

The following indicators were used to assess the reliability of the model: AVE (Average Variance Extracted) above 0.5 (Chin \& Newsted, 1999; Chin, Salisbury, Pearson, \& Stollak, 1999), acceptable Cronbach's alpha of 0.6 , and 0.7 above desirable, composite reliability higher than 0.6 , and extracted commonality higher than 0.50 . Though Cronbach's alpha is the most widely used method to verify the reliability of psychometric scales (Iacobucci \& Duhacheck, 2013), we also included the analysis of composite reliability and communality of the variables, predicting that the distribution of the data was not adhering to the Gauss curve (Nunnally \& Bernstein, 1994).

In the first attempt at applying the PLS-SEM, there was a relationship between the variables and their constructs and by analyzing the factor loadings, the variable (NOST02 - Things used to be better in the good old days), which showed a lower load than 0.5 , was excluded. In the new round, there was no incidence of loads lower than 0.5 . 


\section{Testing the discriminant validity}

Analysis of discriminant validity as suggested by Gefen and Straub (2005) was used. By this method, the discriminant validity is obtained when the square root of the AVE of the construct is greater than the correlation between it and the other constructs of the structural model (Chin \& Newsted, 1999; Gefen \& Straub, 2005). The results of this analysis are shown in Table 3.

Table 3

\section{Results of the Test of Discriminant Validity}

\begin{tabular}{lccccccccccc}
\hline Constructs & AVE & $\begin{array}{l}\text { Composite } \\
\text { Reliability }\end{array}$ & $\mathrm{h}^{2}$ & Alpha & 1 & 2 & 3 & 4 & 5 & 6 & 7 \\
\hline $\begin{array}{l}\text { 1-Attitude } \\
\text { prevailing brand }\end{array}$ & .817 & .969 & .817 & .963 &. $\mathbf{9 0 4}$ & & & & & \\
\hline $\begin{array}{l}2-\text { Attitude extinct } \\
\text { brand }\end{array}$ & .621 & .916 & .621 & .909 & -.202 &. $\mathbf{7 8 8}$ & & & & \\
\hline $\begin{array}{l}3 \quad-\quad \text { Switching } \\
\text { Costs }\end{array}$ & .526 & .844 & .526 & .772 & .395 & -.076 & .725 & & & \\
\hline $\begin{array}{l}4 \quad \text { Attitudinal } \\
\text { Loyalty }\end{array}$ & .780 & .955 & .780 & .943 & .891 & -.193 & .427 & $\mathbf{. 8 8 3}$ & & \\
\hline $\begin{array}{l}5 \quad-\quad \text { Behavioral } \\
\text { Loyalty }\end{array}$ & .525 & .845 & .525 & .781 & .517 & -.148 & .459 & .551 & .724 & \\
\hline \begin{tabular}{l}
$6-$ Nostalgia \\
\hline - Propensity
\end{tabular} & .537 & .803 & .537 & .735 & -.082 & .472 & .005 & - & .054 & .018 & $\mathbf{. 7 3 3}$ \\
\hline
\end{tabular}

Note. Source: research data.

*Highlighted cells indicate the square root of the AVE of the constructs. The others represent the correlation between them.

After verifying the convergent and discriminant validity and the adequacy of the indicators of the model, the structural relationships of the proposed model were analyzed. Figure 2 shows the structural load paths as well as their significance.

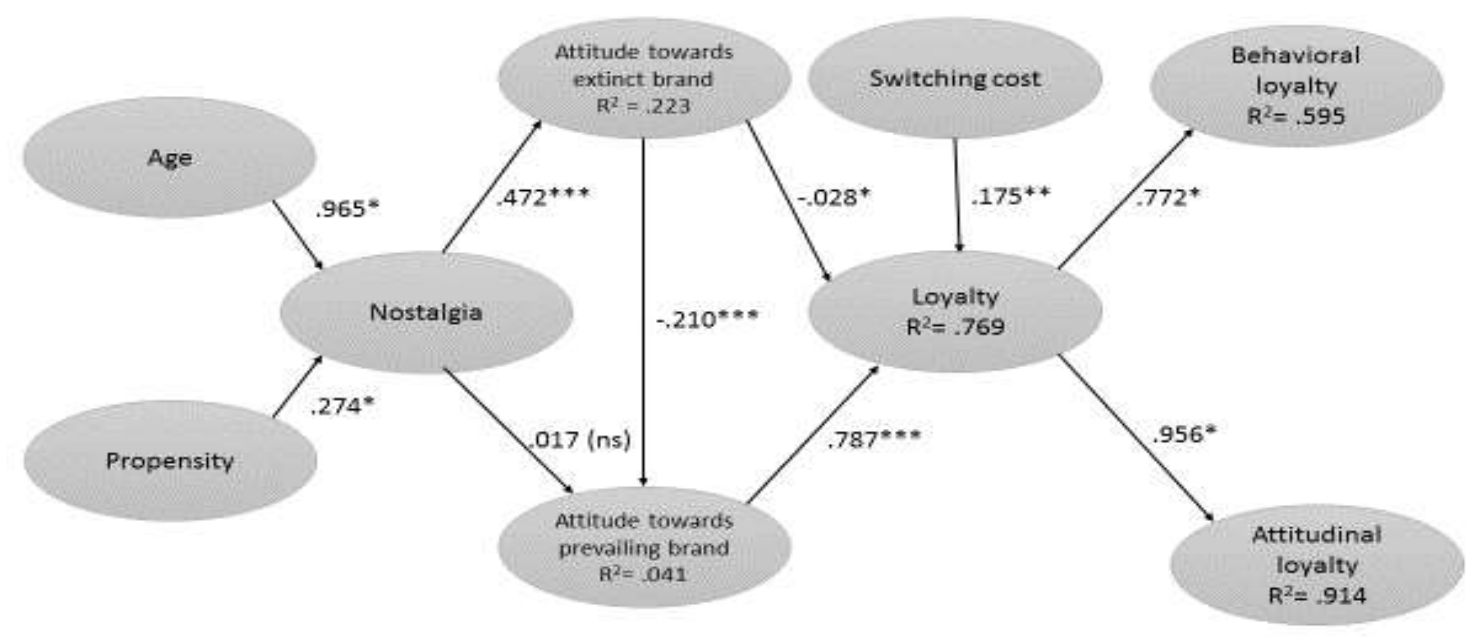

Figure 2. Proposed Structural Model

$*$-value $<0.001 * *$-value $<0.01 * * *$ p-value $<0.05$ and $(n s)=$ not significant 
Aiming to verify the significance of the factor loadings of each path, we carried out the procedure by bootstrap resampling with 100 sub-samples of 200 observations, the results of which are shown in Table 4.

The test enabled a demonstration of the significance of nine structural paths. Only the path between nostalgia and the prevailing attitude toward brand showed no significant load, which resulted in a lack of support for Hypothesis $3 \mathrm{~b}$.

Table 4

Analysis of the Coefficients of the Paths, by Bootstrapping

\begin{tabular}{|c|c|c|c|c|c|c|c|}
\hline Hypotheses & Paths & $\begin{array}{c}\text { Original } \\
\text { sample }\end{array}$ & $\begin{array}{c}\text { Sample } \\
\text { mean of } \\
100\end{array}$ & $\begin{array}{l}\text { Standard } \\
\text { deviation }\end{array}$ & $\begin{array}{l}\text { Standard } \\
\text { Error }\end{array}$ & t Test & p-value \\
\hline $\mathrm{H} 1$ & Age $=>$ Nostalgia & .274 & .274 & .276 & .062 & 4.39 & $\mathrm{p}<.01$ \\
\hline $\mathrm{H} 2$ & Propensity to Nostalgia $=>$ Nostalgia & .965 & .965 & .960 & .026 & $3 ., 65$ & $\mathrm{p}<.001$ \\
\hline $\mathrm{H} 3 \mathrm{a}$ & $\begin{array}{l}\text { Nostalgia } \Rightarrow \text { Attitude toward the } \\
\text { extinct brand }\end{array}$ & .472 & .469 & .451 & .355 & 2.33 & $\mathrm{p}<.05$ \\
\hline $\mathrm{H} 3 \mathrm{~b}$ & $\begin{array}{l}\text { Nostalgia } \Rightarrow \text { Attitude toward the } \\
\text { prevailing brand }\end{array}$ & .017 & -.082 & -.089 & .104 & 0.79 & n.s \\
\hline $\mathrm{H} 3 \mathrm{c}$ & $\begin{array}{l}\text { Attitude toward the extinct brand=> } \\
\text { Attitude toward the prevailing brand }\end{array}$ & -.210 & -.202 & -.203 & .100 & 2.10 & $\mathrm{p}<.05$ \\
\hline $\mathrm{H} 4 \mathrm{a}$ & $\begin{array}{l}\text { Attitude toward the extinct brand=> } \\
\text { Loyalty }\end{array}$ & -.028 & -.093 & -.187 & .093 & 2.08 & $\mathrm{p}<.05$ \\
\hline $\mathrm{H} 4 \mathrm{~b}$ & $\begin{array}{l}\text { Attitude toward the prevailing brand } \\
\Rightarrow>\text { Loyalty }\end{array}$ & .787 & .786 & .782 & .056 & 14.06 & $\mathrm{p}<.001$ \\
\hline H5a & Loyalty $=>$ Behavioral Loyalty & .772 & .773 & .777 & .038 & 20.07 & $\mathrm{p}<.001$ \\
\hline $\mathrm{H} 5 \mathrm{~b}$ & Loyalty $=>$ Attitudinal Loyalty & .956 & .956 & .957 & .009 & 107.24 & $\mathrm{p}<.001$ \\
\hline H6 & Switching Costs $=>$ Loyalty & .175 & .174 & .180 & .060 & 2.92 & $\mathrm{p}<.01$ \\
\hline
\end{tabular}

Note. The critical values for $t(99$ g. 1 . $): \mathrm{p}<10 \%=1.65 ; \mathrm{p}<5 \%=1.96$ e $\mathrm{p}<1 \%=2.60 \mathrm{p}<0.1 \%=5.71$.

As expected, the age of the respondents (H1) and their propensity to feel nostalgic (H2) showed a positive relationship with nostalgia measured in the studied context. This result confirms previous studies in which the same relationship (Batcho, 2013; Holbrook \& Schindler, 1991; Sierra \& Mcquitty, 2007) was observed.

Also identified was a positive relationship between nostalgia and attitude in relation to the former brand, confirming Hypothesis H3a. The emotional evaluation in relation to brand absorbed, reflected the attitude manifested by the respondent, is positively affected by nostalgia. As anticipated in the theoretical review, studies on the relationship between attitude and nostalgia are still incipient and disaggregated (Najmi et al., 2012) mainly when the framework of the work focuses on emotional assessment (Ellwood, 2004).

One finding of this study is the observation of the negative relationship between nostalgia and the prevailing attitude toward brand (H3b), not confirming previous studies on the topic (Ellwood, 2004). Moreover, it has shown that the prevailing attitude toward the brand is influenced by the attitude of the respondent in relation to the former brand $(\mathrm{H} 3 \mathrm{c})$. This result can be understood as a warning to marketing managers and organizations that acquire other brands in the market, especially when the acquired brand enjoys a good reputation and is admired by its customers.

We also identified the indirect influence of nostalgic feelings on consumer loyalty. As proposed in the model developed with theoretical bases, attitudes toward extinct brands mediate the effects of 
nostalgia on consumer loyalty. As recommended by Baron and Kenny (1986), this result was confirmed through the mediation of a post hoc Sobel test $(\mathrm{z}=-1.995)$ and was calculated using the coefficient of the division of charges of indirection (Nostalgia $=>$ Attitudes toward extinct brands $=>$ Loyalty) by the square root of the square sum of the product between the load and standard errors estimated on structural modeling (Sobel, 1982). Even if Hypothesis H3b was not confirmed, probably because the sample individuals remained in the business relationship with the new brand, and therefore they are not part of the most radical individuals when compared to customers who left the bank after the merger of the brands, there is evidence that the indirect effect of nostalgia on loyalty is a real and present phenomenon. Furthermore, the examination of loyalty as performed in this study is in line with the procedure adopted in most academic works that analyzed the same construct (Harter, Schmidt, \& Hayes, 2002; Palmatier, Dant, Grewal, \& Evans, 2006; Sirdeshmukh, Singh, \& Sabol, 2002; Szymanski \& Henard, 2001). The operation of loyalty is also supported by the objective of this study, which is to identify the effect of nostalgia on loyalty, rather than on consumer exchange or abandonment behavior.

Even using a sample of customers who remained with the new service provider, we identified a negative relationship between attitude toward the extinct brand (H4a) and customer loyalty, as well as a positive relationship between attitude toward the prevalent brand and loyalty, thus confirming hypothesis $4 \mathrm{~b}$. This phenomenon indicates the effect of the importance of the brand (Brito, 2010; Keller, 2003) in maintaining consumer loyalty.

Data analysis identified positive relationships between behavioral loyalty (H5a) and between loyalty and attitudinal loyalty and prevailing brand loyalty (H5B). Predictably, the two-dimensional configuration of loyalty (Sheth et al., 2001) was confirmed in this study.

Finally, the observed result of the test of hypothesis 6 supports the literature regarding the effect of the change on the cost of maintenance of consumer loyalty. As expected, because it is a segment of the high cost of change as it is quite laborious to transfer all financial commitments to another banking institution, switching costs showed a positive relationship with loyalty. Even if the result of the path was significant, its coefficient of variance explained little in terms of loyalty, because much of the coefficient of determination of the construct $\left(\mathrm{R}^{2}=0.769\right)$ is explained by the prevailing attitude toward brand. Therefore, once again an alert is made to marketing managers operating in the banking sector: the switching cost, per se, is not sufficient to ensure consumer loyalty in a scenario of merger/acquisition of brands, not even the manifestation of an artificial loyalty as provided by Gonçalves, Gonçalves, Ferreira and Veiga (2009).

\section{Discussion of Results and Final Considerations}

This study aimed to examine the effect of the nostalgic feeling in consumer behavior and loyalty to the prevailing brand, after the extinction of a brand, in the wake of a merger/acquisition process, culminating with the proposition and test of an explanatory model of the relationship between these constructs.

Initially, the researchers reviewed the theoretical framework of the constructs in question: attitude, brand loyalty, switching costs, and nostalgia. Further, we proposed a conceptual model based on a specific situational context: the merger of two banks, with a consequent suppression of brands. The proposed model was tested and validated by empirical research, descriptive and quantitative in nature, with the use of structural equation modeling, specifically the PLS-SEM technique, and based on data collected from customers of Banco Santander who had relationships with ABN/Amro Real prior to the merger.

The hypotheses of the proposed theoretical model were tested for reliability and validity and were accepted. The model showed a high degree of general adjustment, or explained variance, represented by coefficient $\mathrm{R}^{2}=0.769$, referring to construct loyalty and the underlying relationships between the 
constructs of the idealized model. It also achieved the aims in the study and the hypotheses were supported.

The methodological approach resulted in the acceptance of all the hypotheses, with the exception of $\mathrm{H} 3 \mathrm{~b}$, specifically the assumption that customers with the most nostalgic feelings tend to have less favorable opinions regarding the prevailing brand.

The major theoretical contribution of this study is to identify the effect of nostalgia on behavioral attitudes and, indirectly, on consumer loyalty in the context of mergers and acquisitions of service brands. Even though the study of the major constructs of the theoretical model is not new to the applied social sciences, especially for marketing, the importance of advancement in the thematic study should be noted, particularly in a social context as effervescent as the scene of mergers and acquisitions of banks.

Another academic contribution of this study is that it opens up a line for research aimed at the exploration of the construct of nostalgia, which goes beyond conventional research in communication and the tendency to use the retro concept and the revival of extinct brands. This study also contributes to an evaluation of a scale in the Brazilian context linking nostalgia with loyalty, allowing a new perspective of analysis of the nostalgia construct in the sphere of consumer behavior.

Another contribution, of a methodological nature, was to add various constructs in a single model, namely, nostalgia, attitude to brand loyalty, and switching costs. The choice of a merger and acquisition scenario enabled a more accurate perception of the impact of the acquisition phenomenon and the impact on the attitude and behavior of the client with respect to the prevailing brand.

From a managerial perspective, the study focused on consumer behavior. This revealed factors influencing attitude and brand loyalty, including the need to give consistency to the customer relationship as a management tool, deliver more relevant value to customers, establish lasting ties with them and understand how consumers feel about a brand and the nostalgic bond they form with it. This will allow companies to develop strategies that strengthen that bond by associating it with a historical component, referring to an experience the client lived through in the past. Bank marketing managers, for example, can use nostalgic appeals within integrated marketing communication campaigns, minimizing the negative effects of nostalgic feelings in attitudes to prevailing brands and a customer's loyalty to a bank whose brand is being discontinued.

Limitations are inherent in any research approach, especially in the field of applied social sciences. A limitation of this study is related to the selection of respondents for the sample, which did not result from random choice but from convenience, precluding a generalization of the findings of empirical research. Moreover, most clients in the sample lived in and had bank accounts in São Paulo city, which narrowed the extrapolation of the results precluding clients with more diverse relationships with banks, or clients from other banks who experienced the same process of merger/acquisition.

Moreover, the decision to focus on the utilization of customers who remained loyal in the relationship with the new bank limits the power of analysis on the effect of nostalgia on attitudes and loyalty. To mitigate this effect, we recommend that future studies also analyze the effect of nostalgia on consumers who migrate to other institutions after the acquisition/merger.

Currently, several acquisitions are taking place in various economic sectors, including health insurance, food, pharmaceuticals and TV subscription services. The analysis of the theoretical model proposed in other contexts might contribute to the advancement of knowledge of the phenomenon.

Nevertheless, research on the nostalgia construct is not limited to a specific study linked to brand loyalty in a merger/acquisition. It is possible to extend it to other contexts such as the use of nostalgia in advertising to increase the client's link with the brand, the relaunch of products to arouse the feeling of nostalgia in customers and the stimulation and invigoration of a relationship. 
Finally, it is reasonable to assume that the past behavior of the consumer, either by frequency of use or by turnover maintained by the corporate bank, may moderate the relationship between nostalgia and loyalty to the prevailing brand. It is also possible to assume, based on the context used for the operationalization of this study, that the customer's perception of the strength of the prevailing brand may influence the relationship between the variables of the relational model studied. Therefore, we believe that the inclusion of other variables in the model used in this study may represent a breakthrough for the academia and for managers.

\section{Acknowledgments}

The authors acknowledge the valuable contributions made by anonymous reviewers during the review process of this work.

\section{References}

Almeida, S. O., Mazzon, J. A., Dholakia, U., \& Müller, H. F. M., Neto. (2011). Os efeitos da participação em comunidades virtuais de marca no comportamento do consumidor: proposição e teste de um modelo teórico. Revista de Administração Contemporânea, 15(3), 366-391. Retrieved from http://www.scielo.br/pdf/rac/v15n3/v15n3a02. doi: 10.1590/S1415-65552011000300002

Almeida, S. O., Mazzon, J. A., Müller, H. F. M., Neto, \& Dholakia, U. (2012). Efeitos da comunidade de origem no participante de comunidades virtuais de marca. Revista de Administração de Empresas, 52(2), 204-216. doi: 10.1590/S0034-75902012000200007

Baker, S. M., \& Kennedy, P. F. (1994). Death by nostalgia: a diagnostic of context-specific-cases. Proceedings of NA - Advances in Consumer Research, Provo, UT, USA, 21.

Baron, R. M., \& Kenny, D. A. (1986). The moderator-mediator variable distinction in social psychological research: conceptual, strategic, and statistical considerations. Journal of Personality and Social Psychology, 51(6), 1173-1182. doi: 10.1037/0022-3514.51.6.1173

Batcho, K. I. (2013). Nostalgia: the bittersweet history of a psychological concept. History of Psychology, 16(3), 165-176. doi: 10.1037/a0032427

Baumgartner, H. (1992). Remembrance of things past: music, autobiographical memory, and emotion. Proceedings of NA - Advances in Consumer Research, Provo, UT, USA, 19.

Bellaaj Gargouri, R., \& Akrout, F. (2008, January). Nostalgie et fidélité du consommateur: le rôle médiateur de l'attachement à la marque. Proceedings of International Congress Marketing Trends, Venice, Italy, 7. Retrieved from http://www.marketing-trendscongress.com/archives/2008/Materiali/Paper/Fr/Bellaaj_Akrout.pdf

Bittencourt, W. R., Paim, J. V. A., Cunha, J. V. A., da, \& Nascimento, E. M. (2015). Estudo sobre a evolução da concentração do setor bancário no Brasil e da taxa de juros. Revista de Gestão, Finanças e Contabilidade, 5(3), 5-25. doi: 10.18028/2238-5320/rgfc.v5n3p5-25

Boym, S. (2002). The future of nostalgy. New York: Perseus Books Group: Basic Book.

Brakus, J. J., Schimitt, B. H., \& Zarantonello, L. (2009). Brand experience: what is it? How is it measured? Does it affect loyalty? Journal of Marketing, 73(3), 52-68. doi: 10.1509/jmkg.73.3.52

Brito, C. M. (2010). Uma abordagem relacional ao valor da marca. Revista Portuguesa e Brasileira de Gestão, 9(1/2), 49-63. Retrieved from http://www.scielo.mec.pt/pdf/rpbg/v9n1-2/v9n1-2a06.pdf 
Burnham, T. A., Frels, J. K., \& Mahajan, V. (2003). Consumer switching cost: a typology, antecedents, and consequences. Journal of the Academy of Marketing Science, 31(2), 109-126. doi: $10.1177 / 0092070302250897$

Chaplin, S. (2000). The psychology of time and death. Ashland, OH: Sonnet Press.

Chin, W. W., \& Newsted, P. R. (1999). Structural equation modeling analysis with small samples using partial least squares. In R. H. Hoyle (Ed.), Statistical strategies for small sample research (pp. 307-341). Thousand Oaks: Sage Publications.

Chin, W. W., Salisbury, W. D., Pearson, A. W., \& Stollak, M. J. (1999). Perceived cohesion in small groups adapting and testing the perceived cohesion scale in a small-group setting. Small Group Research, 30(6), 751-766. doi: 10.1177/104649649903000605

Comasseto, B. H., Solalinde Z., G. P., Souza, J. V. R. de., Trevisan, M., Abdala, P. R. Z., \& Rossi, C. A. V. (2013). Nostalgia, anticonsumo simbólico e bem-estar: a agricultura urbana. Revista de Administração de Empresas, 53(4), 364-375. doi: 10.1590/S0034-75902013000400004.

Cooper, D. R., \& Schindler, P. S. (2003). Métodos de pesquisa em administração. Porto Alegre: Bookman.

Davis, F. (1979). Yearning for yesterday: sociology of nostalgy. Nova York: The Free Press.

Devellis, R. F. (2003). Scale development: theory and applications. London: Sage Publications.

Dick, A. S., \& Basu, K. (1994). Customer loyalty: towards an integrated conceptual framework. Journal of the Academy of Marketing Science, 2(2), 99-113. doi: 10.1177/0092070394222001

Divard, R., \& Demontrond, P. R. (1997). La nostalgie: um thème récent dans la recherché marketing. Recherche et Applications en Marketing, 12(4), 41-62. doi: 10.1177/076737019701200403

Ellwood, I. (2004). O livro essencial das marcas: tudo o que você precisa saber, em mais de 100 técnicas para aumentar o valor das marcas. São Paulo: Clio Editora.

Ferreira, H. C. B., \& Lima, J. P. R. (2014). A insustentável leveza do ter: crédito e consumismo no Brasil. Revista da Sociedade Brasileira de Economia Política, (38), 58-88. Retrieved from http://revista.sep.org.br/index.php/SEP/article/view/55/92

Field, A. (2009). Discovering statistics using SPSS. London: Sage Publications.

Figueiredo-Neto, C., \& Bacha, M. L. (2013). Persuasores improváveis. Sociedade brasileira de estudos interdisciplinares da comunicação. Anais do Congresso Brasileiro de Ciências da Comunicação, Manaus, AM, Brasil, 36.

Fournier, S. (1998). Consumers and their brands: developing relationship theory in consumer research. The Journal of Consumer Research, 24(1), 343-373. doi: 10.1086/209515

Foxall, G. R., Goldsmith, R. E., \& Brown, S. (1998). Consumer psychology for marketing. London: International Thomson Business Press.

Garrán, V. G. (2006). A influência dos aspectos visuais da embalagem na formação das atitudes do consumidor: um estudo no setor de alimentos (Dissertação de mestrado). Pontifícia Universidade Católica de São Paulo, São Paulo, SP, Brasil.

Gastal, F. (2005). A influência da satisfação e dos custos de mudança na lealdade do cliente (Dissertação de mestrado). Universidade Federal do Rio Grande do Sul, Porto Alegre, RS, Brasil.

Gefen, D., \& Straub, D. (2005). A practical guide to factorial validity using PLS-Graph: tutorial and annotated example. Communications of the Association for Information Systems, 16(1), 91-109. 
Gobe, M. (2010). Emotional branding: the new paradigm for connecting brands to people. New York: Allworth Press.

Gonçalves, C. A., Gonçalves, C., Filho, Ferreira, P. A. G., \& Veiga, R. T. (2009). Antecedentes da lealdade do consumidor: um estudo empírico no mercado de telefonia celular. Revista de Ciências da Administração, 11(24), 136-168. doi: 10.5007/2175-8077.2009v11n24p136

Goulding, C. (2001). Romancing the past: heritage visiting and the nostalgic consumer. Psychology and Marketing, 18(1), 565-580. doi: 10.1002/mar.1021

Hair, J. F., Jr., Money, A., Babin, B., \& Samouel, P. (2005). Fundamentos de métodos de pesquisa em administração. São Paulo: Bookman.

Harter, J. K., Schmidt, F. L., \& Hayes, T. L. (2002). Business-unit-level relationship between employee satisfaction, employee engagement, and business outcomes: a meta-analysis. Journal of Applied Psychology, 87(2), 268-279. doi: 10.1037//0021-9010.87.2.268

Henseler, J., Ringle, C. M., \& Sinkovics, R. R. (2009). The use of partial least squares path modeling in international marketing. Advances in International Marketing, 20(2), 277-319. doi: 10.1108/S1474-7979(2009)0000020014

Hertz, D. G. (1990). Trauma and nostalgia: new aspects of the coping of aging holocaust survivors. Israeli Journal of Psychiatry and Related Sciences, 27(2), 189-198.

Ho, C. Y. (2015). Switching cost and deposit demand in China. International Economic Review, 56(3), 723-749. doi: $10.1111 /$ iere. 12120

Holak, S., \& Havlena, W. (1998). Feelings, fantasies, and memories: an examination of the emotional components of nostalgia. Journal of Business Research, 42(1), 217-226. doi: 10.1016/S01482963(97)00119-7

Holbrook, M. B. (1993). Nostalgia and consumption preferences: some emerging patterns of consumer tastes. Journal of Consumer Research, 20(1), 245-256. doi: 10.1086/209346

Holbrook, M. B., \& Schindler, R. (1991). Echoes of the dear departed past: some work in progress on nostalgia. Proceedings of NA - Advances in Consumer Research, Provo, UT, USA, 18.

Holbrook, M. B., \& Schindler, R. (2003a). Nostalgia for early experience as a determinant of consumer preferences. Psychology \& Marketing, 20(4), 275-302. doi: 10.1002/mar.10074

Holbrook, M. B., \& Schindler, R. (2003b). Nostalgic bonding: exploring the role of nostalgia in the consumption experience. Journal of Consumer Behavior, 3(2), 107-127. doi: 10.1002/cb.127

Hunt, L., \& Johns, N. (2013). Image, place and nostalgia in hospitality branding and marketing. Worldwide Hospitality and Tourism Themes, 5(1), 14-26. doi: $10.1108 / 17554211311292411$

Iacobucci, D., \& Duhachek, A. (2003). Advancing alpha: measuring reliability with confidence. Journal of Consumer Psychology, 13(4), 478-487. doi: 10.1207/S15327663JCP1304_14

Kanungo, R. N. (1979). The concept of alienation and involvement revisited. Psychological Bulletin, 86(1), 119-138. doi: 10.1037/0033-2909.86.1.119

Kaplan, H. A. (1987). The psychopathology of nostalgia. Psychoanalytic Review, 74(1), 465-486. doi: $10.1037 / \mathrm{a} 0027236$

Keller, K. L. (2003). Strategic brand management: building, measuring, and managing brand equity. New Jersey: Prentice Hall. 
Keller, K. L., \& Lehmann, D. (2006). Brands and branding: research findings and future priorities. Marketing Science, 25(6), 740-759. doi: 10.1287/mksc.1050.0153

Kim, M., Kliger, D., \& Vale, B. (2003). Estimating switching costs: the case of banking. Journal of Financial Intermediation, 12(1), 25-56. doi: 10.1016/S1042-9573(02)00005-0

Klemperer, P. (1995). Competition when consumer have switching cost. Review of Economic Studies, 62(1), 515-539. doi: 10.2307/2298075

Larán, J. A., \& Espinoza, F. S. (2004). Consumidores satisfeitos, e então? Analisando a satisfação como antecedente da lealdade. Revista de Administração Contemporânea, 8(2), 51-70. doi: $10.1590 / \mathrm{S} 1415-65552004000200004$

Lefi, L., \& Gharbi, A. (2011). Nostalgia and brand attachment: theoretical framework and application in the case of a Tunisian advertising. Journal of Business Studies Quartely, 3(1), 187-200.

Marchegiani, C., \& Phau, I. (2011). The value of historical nostalgia for marketing management. Marketing Intelligence \& Planning, 29(2), 108-122. doi: 10.1108/0263450111111757.

Mathwick, C., \& Rigdon, E. (2004). Play, flow, and the online search experience. Journal of Consumer Research, 31(2), 324-332. doi: 10.1086/422111

Matos, C. A. (2011). Uma generalização empírica sobre comunicação boca a boca usando metanálise. Revista de Administração Contemporânea, 15(5), 877-896. Retrieved from http://www.scielo.br/pdf/rac/v15n5/a06v15n5.pdf. doi: 10.1590/S1415-65552011000500006

Merchant, A., \& Ford, J. (2008). Nostalgia and giving to charity: a conceptual framework for discussion and research. International Journal of Nonprofit and Voluntary Sector Marketing, 13(1), 13-30. doi: $10.1002 /$ nvsm.300

Muehling, D. D. (2013). The relative influence of advertising-evoked personal and historical nostalgic thoughts on consumers' brand attitude. Journal of Marketing Communications, 19(2), 98-113. doi: $10.1080 / 13527266.2011 .560613$

Muehling, D. D., \& Pascal, V. J. (2012). An involvement explanation for nostalgia advertising effects. Journal of Promotion Management, 18(1), 100-118. doi: 10.1080/10496491.2012.646222

Muehling, D. D., \& Sprott, D. E. (2004). The power of reflection: an empirical examination of nostalgia advertising effects. Journal of Advertising, 33(3), 25-35. doi: 10.1080/00913367.2004

Najmi, M., Atefi, Y., \& Mirbagheri, S. A. (2012). Attitudes toward brand: an integrative look at mediators and moderators. Academy of Marketing Studies Journal, 16(1), 111-133. doi: 10.2753/JEC1086-4415180104

Newman, J. W., \& Werbel, R. A. (1973). Multivariate analysis of brand loyalty for major household appliances. Journal of Marketing Research, 10(4), 404-409. doi: 10.2307/3149388

Nunnally, J. C., \& Bernstein, I. H. (1994). The assessment of reliability. Psychometric Theory, 3(1), 248-292.

Oliveira, R. F. B., \& Ferreira, P. (2012). Influência da experiência de marca na atitude e intenção de compra: o caso Red Bull. Proceedings of Tourism and Management Studies International Conference, Algarve, Portugal, 1.

Oliver, R. L. (1999). Whence customer loyalty? Journal of Marketing, 63(6), 33-44. doi: $10.2307 / 1252099$ 
Palmatier, R. W., Dant, R. P., Grewal, D., \& Evans, K. R. (2006). Factors influencing the effectiveness of relationship marketing: a meta-analysis. Journal of Marketing, 70(4), 136-153. doi: $10.2139 /$ ssrn. 90464

Perillo, R. D. (2007). Avaliando a relação entre satisfação e lealdade dos clientes: estudo em uma população formada por consumidores de produtos e serviços bancários (Tese de doutorado). Instituto de Psicologia, Universidade de Brasília, Brasília, DF, Brasil.

Plutarco, F., \& Botelho, D. (2012, setembro). A volta dos velhos e bons tempos: proposições sobre o construto nostalgia na área de comportamento do consumidor. Anais do Encontro Nacional da Associação Nacional de Pós-Graduação e Pesquisa em Administração, Rio de Janeiro, RJ, Brasil, 36.

Richardson, R. J. (1989). Pesquisa social: métodos e técnicas. São Paulo: Atlas.

Romaniuk, J., \& Thiel, M. N. (2013). Thought leadership in brand management. Journal of Business Research, 66(1), 67-72. doi: 10.1016/j.jbusres.2012.07.006

Sedikides, C., Wildschut, T., \& Baden, D. (2004). Nostalgia: conceptual issues and existential functions. In J. Greenberg, S. Koole, \& T. Pyszczynski (Eds.), Handbook of experimental existential psychology (pp. 200-214). New York: Guilford.

Shen, N. (2014). Consumer rationality/irrationality and financial literacy in the credit card market: implications from an integrative review. Journal of Financial Services Marketing, 19(1), 29-42. doi: $10.1057 /$ fsm.2014.4

Sheth, J. N., Mittal, B., \& Newman, B. I. (2001). Comportamento do cliente: indo além do comportamento do consumidor. São Paulo: Editora Atlas.

Sierra, J. J., \& Mcquitty, S. (2007). Attitudes and emotions as determinants of nostalgia purchases: an application of social identity theory. Journal of Marketing Theory and Practice, 15(2), 99-112. doi: 10.2753/MTP1069-6679150201

Sirdeshmukh, D., Singh, J., \& Sabol, B. (2002). Consumer trust, value, and loyalty in relational exchanges. Journal of Marketing, 66(1), 15-37. doi: 10.1509/jmkg.66.1.15.18449

Sobel, M. E. (1982). Asymptotic confidence intervals for indirect effects in structural equation models. Sociological Methodology, 13(1), 290-312. doi: 10.2307/270723

Stern, B. B. (1992). Historical and personal nostalgia in advertising text: the fin de siècle effect. Journal of Advertising, 21(3), 11-22. doi: 10.1080/00913367.1992.10673382

Sugimori, E., Matsuda, K., \& Kusumi, T. (2011). The contradictory effects of nostalgic advertisements on nostalgia for products and on remembering advertisements. Japanese Psychological Research, 53(1), 42-52. doi: 10.1111/j.1468-5884.2010.00454.x

Szymanski, D. M., \& Henard, D. H. (2001). Customer satisfaction: a meta-analysis of the empirical evidence. Journal of the Academy of Marketing Science, 29(1), 16-35. doi: $10.1177 / 009207030102900102$

Werman, D. S. (1977). Normal and pathological nostalgia. Journal of the American Psychoanalytic Association, 25(1), 387-398. doi: 10.1177/000306517702500205

Wildschut, T., Sedikides, C., Arndt, J., \& Routledge, C. (2006). Nostalgia: content, triggers, functions. Journal of Personality and Social Psychology, 91(5), 975-993. doi: 10.1037/00223514.91.5.975 


\section{Authors' Profiles}

Ana Carolina Toledo

Av. Francisco Matarazzo, 12, 055011-000, São Paulo, SP, Brazil. E-mail address: ana.caro.toledo@uol.com.br

Evandro Luiz Lopes

Av. Francisco Matarazzo, 12, 055011-000, São Paulo, SP, Brazil. E-mail address: elldijo@uol.com.br, elldijo@uninove.br 